\title{
Menyoal Keabsahan Hadits-Hadits Keintiman; Studi Analisis Kitab Qurratul Uyun Karya Syaikh Muhammad Al-Tahami bin Madani
}

\author{
Khairul Muttaqin \\ Institut Agama Islam Negeri Madura \\ muttaqin.ilunks@gmail.com
}

\begin{abstract}
Qurratul Uyun is a book in which many explain about marriage. The book created by Syaih Muhammad al-Tahami bin Madani. The book is widely found and taught in the huts of salaf boarding schools in order to provide knowledge that is populated for student who want to get married. One discussion in the Qurratul Uyun is about intimate relationships include the right day and the inappropriate for intercourse, intercourse and intercourse reward. The discussions are explained by quoting the Prophet's hadiths to corroborate the discussion. However, the hadith which is used as the foundation is not all shahih but there are some hadits whose quality is dha'if even maudhu'. The method used in this paper is the method of library research where more refers to the sources of books in the form of books of hadith and books biography of the hadith narration in researching the quality of the hadith. After a thorough study, it was found that not all of the hadiths of intimacy mentioned in the Qurratul Uyun are worth dha'if. There are some who are shahih and can be used as a legal basis. But there are also some hadith intimacy in the book that is worth dha'if so it can't be used as a legal basis. Some of the hadiths are also worth dha'if but supported with other hadiths of better quality so that can still be the basis of law and its content can be practiced.
\end{abstract}

Keywords: Validity, Hadith, Intimacy, Qurratul Uyun

\begin{abstract}
Abstrak
Qurratul Uyun adalah sebuah kitab yang di dalamnya banyak menjelaskan tentang pernikahan. Kitab tersebut merupakan karangan dari Syaih Muhammad al-Tahami bin Madani. Kitab tersebut banyak dijumpai dan diajarkan di pondok-pondok pesantren salaf agar memberikan pengetahuan yang mempuni bagi santri yang hendak menikah. Salah satu pembahasan dalam kitab Qurratul Uyun adalah tentang hubungan intim meliputi hari yang tepat dan yang tidak tepat untuk bersenggama, tata cara bersenggama dan pahala bersenggama. Pemabahasan-pembahasan tersebut dijelaskan dengan mengutip hadits-hadits Nabi untuk menguatkan pembahasan tersebut. Akan tetapi hadits yang dijadikan subagai landasan tidak semuanya shahih namun ada beberapa yang dha'if bahkan maudhu'. Metode yang digunakan dalam tulisan ini adalah metode library research di mana lebih banyak mengacu pada sumber-sumber pustaka berupa kitab-kitab hadits dan kitab-kitab biografi periwayat hadits dalam meneliti kualitas hadits tersebut. Setelah dilakukan telaah secara mendalam didapatkan kesimpulan bahwa tidak semua hadits keintiman yang disebutkan dalam kitab Qurratul Uyun bernilai dha'if. Ada sebagian yang shahih dan bisa dijadikan sebagai landasan hukum. Namun ada juga sebagian hadits keintiman dalam kitab tersebut yang bernilai dha'if sehingga tidak bisa dijadikan sebagai landasan hukum. Sebagian hadits tersebut juga bernilai dha'if namun didukung dengan hadits lain yang kualitasnya lebih baik sehingga tetap bisa dijadikan landasan hukum dan isinya bisa diamalkan.
\end{abstract}

Kata Kunci: Keabsahan, Hadits, Keintiman, Qurratul Uyun 


\section{Pendahuluan}

Kitab kuning adalah karya berbahasa arab yang ditulis oleh ulama'-ulama' salaf al-shalih sebelum abad ke-17 yakni sebelum Islam memasuki era modern dalam Islam. Kitab kuning biasanya ditulis dengan memadukan antara matan ${ }^{1}$ dan syarah $^{2}$, namun ada juga yang ditulis dalam bentuk matan saja atau syarah saja. Di Indonesia kitab kuning biasanya banyak diajarkan di pondokpondok pesantran baik yang pesantren salaf maupun pesantren modern atau semi modern.

Kitab kuning kadang ditulis oleh ulama' asing (biasanya ulama' Arab) yang secara turun-temurun menjadi referensi yang dipakai sebagai pedoman oleh ulama' Indonesia. Kadang kitab kuning ditulis oleh ulama' Indonesia yang sebagai karya mandiri dan merupakan refleksi pemikirannya. Kitab kuning kadang juga ditulis oleh ulama' Indonesia sebagai komentar, penjelasan atau

\footnotetext{
${ }^{1}$ Matan adalah teks inti yang dijelaskan dalam syarah 2 Syarah adalah penjelasan tentang matan
}

tarjamah atau karya-karya ulama' asing. ${ }^{3}$

Sejarah mencatat bahwa sejak era awal adanya pesantren memang sudah menggunakan kitab kuning sebagai buku atau kitab rujukannya. Di sebagian tempat kitab kuning tersebut kadang disebut juga dengan kitab turats. Di tempat yang lain kadang disebut juga dengan kitab gundul karena kitab tersebut disajikan dalam bentuk tidak berharakat (gundul). Kitab tersebut dinamai kitab kuning karena kitab tersebut ditulis atau dicetak menggunakan kertas berwarna kuning. ${ }^{4}$

Penggunaan kitab kuning di pesantren sudah ada sejak nama pesantren belum dikenal. Kitab-kitab yang digunakan di pesantren mengacu kitab-kitab fiqh dengan madzhab Syafi'iyah ${ }^{5}$, teologi beraliran Asy'ariyah dan Maturidiyah dan taswwufnya mengacu pada tasawwuf al-Ghazali dan sejenisnya.

\footnotetext{
3 Zamakhsyari Dhofier, Studi Pesantren; Studi tentang Pandangan Kyai, (Jakarta: LP3ES, 1982), 992

${ }_{4}^{4}$ Dirjen Kelembagaan Agama Islam Departemen Agama, Pondok Pesantren dan Madrasah Diniyah, 32.

${ }^{5}$ HM. Amin Haedari, et.al, Masa Depan Pesantren dalam Tantangan Modernitas dan Tantangan Kompleksitas Global, (Jakarta: IRD Press, 2005), 37.
} 
Salah satu kitab yang sering dikaji di pesantren adalah kitab Qurratul Uyun karya Syaih Muhammad al-Tahami bin Madani. Kitab ini mengupas banyak pembahasan yang berkaitan dengan pernikahan baik sebelum menikah atau setelah menikah. Yang menarik dari kitab tersebut adalah pembahasan tentang hubungan intim suami istri yang disertai dengan dalil-dalil yang berasal dari hadits-hadits Nabi SAW.

Kitab ini menjadi referensi wajid di pondok pesantren bagi para santri yang sudah memasuki usia cukup untuk menikah. Para santri yang usianya sudah cukup akan diberikan pengajian kitab tersebut agar para santri yang nantinya akan menikah dapat memiliki pengetahuan yang cukup memadai tentang hukum pernikahan, manfaat pernikahan bahkan tata cara melakukan hubungan intim yang baik dan benar menurut agama.

Hadits-hadits yang disebutkan dalam kitab tersebut cenderung tidak masuk akal dan melebih-lebihkan. Sehingga menimbulkan pertanyaan lanjutan tentang keabsahan hadits- hadits tersebut. Karena hadits-hadits yang cenderung tidak masuk akal dan berlebih-lebihan biasanya merupakan hadits yang dha'if (lemah) bahkan maudhu' (palsu).

Atas fenomena tersebut maka peneliti menganggap perlu untuk membahas keabsahan hadits-hadits yang disebutkan dalam kitab Qurratul Uyun Tersebut mengingat kitab tersebut menjadi referensi wajib yang selalu dikaji di pondok-pondok pesantren.

\section{Metode Penelitian Hadits}

Hadis shahih adalah hadis yang sanadnya bersambung dengan dinukil dari perawi yang adil dan dhabith dan matannya tidak terdapat illat (penyakit) dan syadz (keganjilan). ${ }^{6}$ Oleh karena itu untuk menentukan hadis itu sanad dan matan nya shahih atau tidak maka harus dilakukan penelitian hadis.

Adapun langkah-langkah dalam melakukan penelitian hadis Nabi menurut M. Syuhudi Ismail adalah sebagai berikut:

6 Teungku Muhammad Hasbi al-Shieddieqy, Sejarah dan Pengantar Ilmu Hadis, (Semarang: Pustaka Rizki Putra, 2009), 162. 


\section{Melakukan Takhrij al-Hadits}

Dalam melakukan penelitian hadits harus dilakukan beberapa Langkah sebagai berikut:

Pertama, Pengertian Takhrij alHadits

Secara etimologis, kata Takhrij, berasal dari kata kharaja, mendapat tambahan tasydid/syiddah pada ra ('ain fi'il) menjadi kharraja yukharriju Takhrijan yang berarti menampakkan, mengeluarkan, menerbitkan, menyebutkan dan menumbuhkan. Maksud dari menampakkan disini tidak mesti berbentuk fisik yang kongkrit, tetapi mencakup non fisik yang hanya memerlukan tenaga dan pikiran seperti makna kata istikhraj yang diartikan istimbat yang berarti mengeluarkan hukum dari nash atau teks Al-Qur'an dan hadis. ${ }^{7}$

Adapun secara terminologis, Takhrij adalah menunjukkan tempat hadis pada sumber-sumber aslinya, dimana hadis tersebut telah diriwayatkan lengkap dengan

7 Abdul Majid Khon, Ulumul Hadits, (Jakarta: Amzah Press, 2010), 115. sanadnya kemudian menjelaskan dengan derajatnya jika diperlukan. ${ }^{8}$

Kedua, Pentingnya Kegiatan Takhrij al-Hadits

Ilmu Takhrij al-Hadits merupakan bagian dari ilmu agama yang penting untuk dipelajari dan dikuasai, karena di dalamya dibicarakan berbagai kaidah untuk mengetahui dari sumber hadis itu berasal. Adapun beberapa hal yang menyebabkan kegiatan hadis itu penting untuk dilaksanakan diantaranya sebagai berikut: 1) Untuk mengetahui asal-usul riwayat hadis yang akan diteliti, 2) Untuk mengetahui seluruh riwayat hadis yang akan diteliti, 3) Untuk mengetahui ada atau tidaknya shahid (periwayat lain pada tingkatan sahabat yang mendukung sanadnya) atau mutabi' (mendukung sanad bukan pada periwayat pertama) pada sanad yang diteliti dan 4) Untuk mengetahui bagaimana pandangan para ulama tentang kesahihan suatu hadis.

Ketiga, Metode Takhrijul Hadits

8 Mahmud Thahhan, Taisir Mustalah al-Hadits, (Bairut: Dar Al-Qur'an Karim, 1979), 14. 
Menelusuri hadis tidak sesulit yang dipikirkan karena hampir sama dengan menelusuri Al-Qur'an yang cukup dengan sebuah kamus alQur'an., misalnya kitab al-Mu'jam alMufahras li Al-fazh Al-Qur'an al-Karim yang disusun oleh Muhammad Fu'ad Abdul Baqi. Begitu pula dengan penelusuran hadis Nabi, peneliti dapat merujuk pada sebuah kitab yang dikarang oleh seorang orientalis yaitu: al-Mu'jam al-Mufahras li Al-fazh al-Syarif al-Nabawy. Akan tetapi dalam kitab itu hanya menghimpun beberapa kitab hadis saja sehingga tidak semua kitab hadis, baik kitab shahih, kitab matan, kitab musnad dan sebagainya, tercakup dalam kitab tersebut.

Ada beberapa metode atau jalan yang dapat ditempuh dalam menTakhrij hadis, yaitu:

Pertama, Melalui pengenalan awal lafaz atau matan hadis (al-Takhrij bi mathla'i al-hadith), yaitu dengan melihat lafaz pertama dalam matan hadis. Jika menTakhrij dengan cara ini peneliti harus tahu betul lafaz pada awal matan hadis. Kitab-kitab yang menjadi rujukan pada metode ini yaitu; Al-Jami' al-Shagir, karya al-
Suyuti, Al-Fath al-Kabir fi Dhammi alZiyadah ila Jami al-Shagir, karya alSuyuti, Jam'u al-Jawami'/al-Jam'u alKabir, karya Suyuti, Al-Jami al-Azhar min Hadits al-Nabi al-Anwar, karya Abdu Rauf Tajudin al-Munawi, Hidayatu al-Bari ila Tartibi Ahadits alBukhari, karya Abdu Rahim al-Tahtawi dan sebagainya.

Kedua, Melalui pengenalan lafaz atau kata-kata yang merupakan bagian dari matan hadis (al-Takhrij bi alfazi al-Hadits). Metode ini dipandang sebagai metode yang paling mudah, karena peneliti cukup mengambil satu atau lebih dari matan hadis, dan bisa dengan cepat mendapatkan hadis yang dimaksud. Kitab yang dijadikan rujukan pada metode ini yaitu alMu'jam al-Mufahras karya Dr. A.J. Wensink, yang disusun berdasarkan huruf abjad.

Ketiga, Melalui pengenalan nama perawi pertama baik sahabat atau tabi'in (al-Takhrij bi wa sithathi alrawi a'la. Untuk bisa menelusuri letak hadis ini, peneliti harus tahu betul nama perawi pertama (akhir al-sanad). Kitab yang dijadikan rujukan pada metode ini adalah: Kutub al-Atraf (atraf 
al-shahihain; karya Abu Mas'ud Ibrahim, Atraf Kutub al-Sitta; karya Syamsudin, al-Ishraf ala Ma'rifati alAtraf; karya Ibnu Asakir), Tuhfatu alAshraf, karya Jamaluddin Abu al-Hajaj al-Syafi'i, Al-Naktu al-Zurraf 'ala alAtraf, karya Ibnu Hajar, Dhakhairu alMawarits, karya Abdul Ghani alDamashq, Kutub al-Masanid, salah satunya adalah Musnad Ibnu Hambal dan sebagainya.

Keempat, Melalui pengenalan topik yang terkandung dalam matan hadis (al-Takhrij binaan 'ala maudlu'i alHadits). Kitab yang dijadikan rujukan pada metode ini banyak sekali diantaranya: Kanzul 'Ummal li Hindi, Bulug al-Maram li Ibni Hajar, Al-Tarhib wa Targib li Mundhiri dan Fathu al-Qadir li Syaukani

Kelima, Melalui pengenalan sifat hadis (al-Takhrij 'ala sifati zahirah fi alhadith), misalnya hadis Qudsi, Mashhur, Mursal atau lainnya. Kitab-kitab yang dijadikan rujukan yaitu: Al-Maqasid alHasanah li Shakhawi, Al-Marasil li Abi Dawud, Al-AHadits Qudsiyah li Lajnah al-Qur'an wa al-Hadits. ${ }^{9}$

9 Abd. Muhdi Abdul Qadir, Turuqu Takhrij Hadith Rasulillah, (Kairo: Dar I'tisahm, 1986), 24.

\section{Penelitian Sanad Hadis}

Adapun langkah-langkah dalam melakukan penelitian sanad hadits adalah sebagai berikut:

Pertama, Melakukan I'tibar ${ }^{10}$ dan membuat sekema sanad

Kedua, Meneliti pribadi periwayat dan metode periwayatannya dengan 1) mengacu pada kaidah kesahihan sanad yakni (bersambung sanadnya dari mukharrij sampai kepada Nabi, seluruh periwayat harus adil dan dhabith dan terhindar dari syadz (kejanggalan) dan illat (cacat), 2) meneliti kualitas pribadi periwayat dan kualitas intelektual periwayat, 3) meneliti periwayat yang ta'dil dan tajrih, 4) meneliti persambungan riwayat dengan melihat guru, murid dan tahun wafatnya dan 5) meneliti syadz dan 'illat. ${ }^{11}$

Ketiga, Menyimpulkan

Hasil dari langkah-langkah penelitian sanad adalah menemukan apakah sanad hadis yang diteliti bersifat mutawatir atau ahad. Jika sanadnya ahad maka ditentukan

10 I'tibar adalah menyertakan sanad yang lain, baik dari syahid atau mutabi', untuk suatu hadis tertentu. ${ }_{11}$ M. Syuhudi Ismail, Metodologi Penelitian Hadis Nabi, (Jakarta: Bulan Bintang, 2007), 60-85. 
apakah hadis ahad itu shahih, hasan atau $d h a^{\prime}$ if. Bila perlu disertakan penjelasan apa hadis itu hasan li dzatihi atau hasan li ghairihi.

\section{Penelitian Matan Hadis}

Kata matan berasal dari bahasa Arab matan yang berarti "punggung jalan" atau "bagian tanah keras yang menonjol ke atas"12 Apabila dirangkai menjadi matan al Hadith, menurut alThibiy, seperti yang dinukil oleh Musfir al-Damini, adalah:

$$
\text { الفاظ الحديث التي تتقوم بها المعاني }
$$

Kata-kata hadis yang dengannya terbentuk makna-makna. ${ }^{13}$

Definisi ini sejalan dengan pandangan Ibnu Al-Atsir al-Jazari (w: 606) bahwa setiap matan hadis tersusun atas elemen lafal (teks) dan elemen makna (konsep). ${ }^{14}$ Dengan demikian, komposisi ungkapan matan hadis pada hakikatnya adalah cerminan konsep ide yang intinya dirumuskan berbentuk teks. Susunan

\footnotetext{
12 Ibnu Mandzur, Lisan al-Arab, (Beirut: Dar Lisan al-Arab, tt), 438-435.

13 Al-Damini, Maqayis Naqd Mutun al-Sunnah, (Riyadh: t.p, 1984), 50.

14 Ibn al-Atsir, al-Nihayah fi Gharib al-Hadis wa alAtsar, Juz I (Mesir: Isa al- Babi, 1963), 4.
}

kalimat dalam matan al-Hadits berfungsi sebagai sarana perumus konsep keagamaan versi Hadis. Teks matan al-Hadits disebut juga nash alHadits atau nash al-riwayah. ${ }^{15}$

Khathib al-Baghdadi menyatakan bahwa unsur-unsur yang matan hadis yang maqbul (diterima karena berkualitas shahih) apabila: ${ }^{16}$ pertama, Tidak bertentangan dengan akal yang sehat, kedua, Tidak bertentangan dengan hukum al-Qur'an yang muhkam, ketiga, Tidak bertentangan dengan hadis mutawatir, keempat, Tidak bertentangan dengan amalan yang telah menjadi kesepakatan ulama' masa lalu (ulama' salaf), kelima, Tidak bertentangan dengan dalil yang telah pasti dan keenam, Tidak bertentangan dengan hadis ahad yang kualitas kesahihannya lebih kuat.

\section{Hadits-Hadits Keintiman Dalam Kitab Qurratul Uyun \\ Syaih Muhammad al-Tahami} bin Madani memulai pembahasan dalam kitab Quratul Uyun dengan

\footnotetext{
15 Al-Adlabi, Manhaj naqd al-matn, (Beirut: Dar al-Afaq al-Jadidah), 30.

16 Khathib Al-Baghdadi, Kitab al-Kifayah Fi Ilm Al-Riwayah, (Mesir: Mathba'ah al-Sa'adah, 1972), 206-207.
} 
menguraikan hukum tentang nikah dan faidah pernikahan. Namum pembahasan tersebut tidak ada kaitannya dengan pembahasan dalam penelitian ini karena penelitian ini menekankan pada hadits-hadits dalam kitab Qurratul Uyun yang berkaitan dengan hubungan intim suami istri saja.

\section{Waktu Bersenggama}

Waktu Yang Dilarang Bersenggama

Hari yang harus dihindari dalam melakukan hubungan suami istri adalah hari rabu yang jatuh pada minggu terakhir tiap bulan, hari ketiga awal tiap bulan ramadhan, hari kelima awal tiap bulan ramadhan, hari ketiga belas pada setiap bulan, hari keenam belas pada setiap bulan, hari keduapuluh satu pada setiap bulan, hari kedua puluh empat pada setiap bulan dan hari kedua puluh lima pada setiap bulan.

Rasulullah SAW bersabda:

$$
\text { يوم الاربعاء في الشهر يوم نحس مستمر }
$$

Hari rabu tiap bulan adalah hari nahas yang berkelanjutan. ${ }^{17}$

17 Muhammad al-Tahami bin Madani, Qurratul Uyun; Fi al-Nikah al-Syar'I, (t.tp: t.p, t.t), 20.
Dalam hadits lain disebutkan:

يوم دم لانه حاضة فيه حواء

Hari rabu adalah hari darah karena Siti Hawa mengalami haid pada hari rabu. ${ }^{18}$

Salah satu hari yang harus dijauhi pada saat hendak melakukan hubungan intim adalah hari sabtu. Hal ini berdasarkan sabda Rasulullah SAW:

$$
\text { يوم مكر وخديعة }
$$

Hari sabtu adalah hari makar dan hari yang penuh tipu daya. ${ }^{19}$

\section{Waktu Yang Tepat Bersenggama}

Disebutkan dalam kitab Qurratul Uyun bahwa disunnahkan berhubungan intim pada malam hari. Hal ini berdasarkan hadits Nabi:

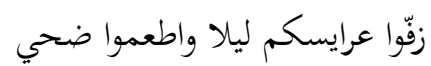

Adakanlah temu penganten kalian, pada malam hari. Dan adakanlah jamuan makan (syukuran resepsi pernikahan) pada waktu dhuha. ${ }^{20}$

Adapun bulan yang tepat untuk menikah dan bersenggama adalah bulan Syawal. Hal ini berdasarkan hadits Nabi:

18 Ibid, 21.

19 Ibid, 21.

${ }^{20}$ Ibid, 20. 


$$
\text { تزوجني رسول الله صلى الله عليه وسلم في شوال وبني بي }
$$

Rasulullah SAW menikahiku (Aisyah) pada bulan Syawal dan melakukan hubungan intim denganku pada bulan Syawal pula. ${ }^{21}$

Hari yang tepat untuk melakukan hubungan suami istri adalah hari minggu. Hal ini berdasarkan hadits Nabi:

$$
\text { يوم غرس وعمارة }
$$

Hari minggu adalah hari menanam dan membangun. ${ }^{22}$

Salah satu hari yang juga dianjurkan untuk berhubungan intim adalah hari jum'at. Hal ini berdasarkan hadits:

$$
\text { يوم نكاح و خطبة ايضا }
$$

Hari jum'at adalah hari menikah dan hari lamaran juga. ${ }^{23}$

\section{Adab Bersenggama}

Doa Sebelum dan Setelah

\section{Bersenggama}

Rasulullah SAW bersabda:

بسم الله اللهم جنبنا الشيطان وجنب الشيطان ما رزقتنا

Dengan nama Allah. Ya Allah, jauhkanlah kami berdua (suami isteri) dari gangguan syaitan serta jauhkan pula syaitan itu dari apa saja yang Engkau rezqikan kepada kami. ${ }^{24}$

$$
\text { الحمد لله الذي خلق من الماء بشرا }
$$

Segala pujian hanya untuk Allah yang menciptakan manusia dari pada air. ${ }^{25}$

\section{Tidak Telanjang Bulat Saat Bersenggama}

Rasulullah SAW bersabda:

$$
\text { اذا جامع احدكم فلا يتجردان بترد الحمارين }
$$

Jika salah satu dari kalian mengumpuli istrinya maka janganlah telanjang seperti telanjangnya dua himar. ${ }^{26}$

$$
\text { اذا جامع احدكم فلا يتجرد بترد الفرس }
$$

Jika salah satu dari kalian mengumpuli istrinya maka janganlah telanjang seperti telanjangnya kuda. ${ }^{27}$

$$
\begin{aligned}
& \text { لايقعنّ احدكم على مرأته كما تقع البهيمة ليكن بينهما } \\
& \text { رسول قيل وما الرسول؟ قال: القبلة والكلام }
\end{aligned}
$$

Janganlah kalian menggauli istrimu seperti binatang tapi seakan-akan diantara kalian berdua terdapat rasul, apa itu rasul? Nabi menjawab: kiblat dan kalam. ${ }^{28}$

\section{Keadaan Jika Suami Ejekulasi \\ Terlebih Dahulu}

Rasulullah SAW bersabda:
${ }^{21}$ Ibid, 20.

22 Ibid, 23.

${ }^{23}$ Ibid, 23. 
ارضوهن فان رضاهن في فروجهن

Puaskanlah istri-istrimu dan kepuasan istri-istrimu berada pada kemaluannya. ${ }^{29}$

الشهوة عشرة اجزاء تسعة للنساء والعاشرة للرجال الا أن الله سترهن بالحياء

Syahwat itu ada sepuluh, 9 syahwat dimiliki perempuan dan yang kesepuluh dimiliki laki-laki, hanya saja Allah menutupi syahwat perempuan tersebut dengan rasa malu. ${ }^{30}$

Hadits tersebut menjelaskan bahwa jika suami ejekulasi terlebih dahulu maka harus pelan-pelan agar istri juga bisa ejekulasi. Hal ini dikarenakan kepuasan istri harus diperhatikan saat bersenggama dan karena sifat pemalunya istri akan sulit menjelaskan pada suami meski tidak merasa puas.

\section{Pahala Bersenggama}

Rasulullah SAW bersabda:

$$
\begin{aligned}
& \text { من اخذ بيد امرأته يراودها كتب الله له حسنة ومحا عنه }
\end{aligned}
$$

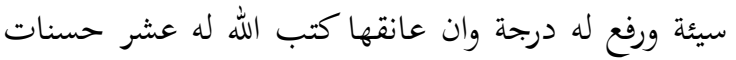

$$
\begin{aligned}
& \text { ومحا عنه عشر سيئات ورفع له عشر درجات وان قبلها } \\
& \text { كتب الله له عشرين حسنة ومحا عنه عشرين سيئة ورفع له } \\
& \text { عشرين درجة وان اتاها كان له خير من الدنيا وما فيها لهان الهان } \\
& \text { Barang siapa yang memegang } \\
& \text { tangan dan mengajak istrinya }
\end{aligned}
$$

maka Allah menuliskan untuknya satu kebaikan, menghapus satu keburukan dan mengangkat satu derajat untuknya. Apabila memeluknya maka Allah menuliskan untuknya sepuluh kebaikan, menghapus sepuluh keburukan dan mengangkat sepuluh derajat untuknya. Apabila menciumnya maka Allah menuliskan untuknya dua puluh kebaikan, menghapus dua puluh keburukan dan mengangkat dua puluh derajat untuknya. Apabila menggaulinya maka mendapatkan sesuatu yang lebih baik dari dunia dan seisinya. ${ }^{31}$

$$
\begin{aligned}
& \text { من لاعب زوجته كتب الله له عشرين حسنة ومحا عنه } \\
& \text { عشرين سيئة فاذا اخذ بيدها كتب الله له اربعين حسنة ومحا لها لهان }
\end{aligned}
$$

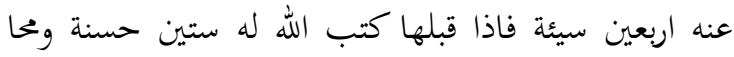

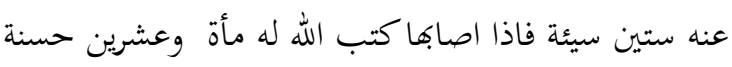

$$
\begin{aligned}
& \text { ومحا عنه مأة وعشرين سيئة فاذا اغتسل نادى الله الملائكة } \\
& \text { فيقول: انظروا الى عبدي يغتسل من خوفي يتيقن إني ربه } \\
& \text { إشهدوا علي بأني قد غفرت له له }
\end{aligned}
$$

Barang siapa yang bersenda gurau dengan istrinya maka Allah menuliskan untuknya dua puluh kebaikan dan menghapus dua puluh keburukan. Apabila memegang tangannya maka Allah menuliskan untuknya empat puluh kebaikan dan menghapus empat puluh keburukan. Apabila menciumnya maka maka Allah menuliskan untuknya enam puluh kebaikan dan menghapus enam puluh keburukan. Apabila menggaulinya maka Allah menuliskan untuknya seratus dua 
puluh kebaikan dan menghapus seratus dua puluh keburukan. Apabila mandi (setelah menggauli) maka Allah memanggil para Malaikat dan berkata: lihatlah hambaku ini, dia mandi karena takut (taqwa) kepadaku dan meyakini bahwa akulah tuhannya. Maka saksikanlah bahwa aku telah mengampuni dosa-dosanya. ${ }^{32}$

\section{Kualitas Keabsahan Hadits-Hadits}

Keintiman Dalam Kitab Qurratul

Uyun

\section{Senggama Pada Hari Rabu dan Sabtu}

Pada pembahasan sebelumnya disebutkan bahwa waktu yang dilarang untuk bersenggama adalah hari rabu dan hari sabtu karena hari rabu adalah hari nahas dan hari sabtu adalah hari makar dan tipu daya.

Setelah dilakukan pencarian pada kitab-kitab hadits ditemukan bahwa hadits yang dijadikan sandaran, bahwa hari rabu dan sabtu tidak baik untuk bersenggama, ditemukan dalam kitab Jami' alShaghir karya Imam Al-Suyuthi. Redaksi haditsnya adalah:

$$
\text { يوم الاربعاء في الشهر يوم نحس مستمر }
$$

${ }^{32} \mathrm{Ibid}, 34$.
Imam al-Baihaqi Menyebutkan dalam kitabnya dengan redaksi hadits dan perawi yang lengkap yakni:33

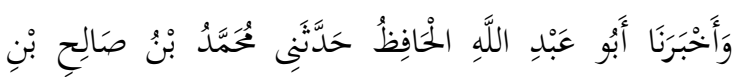

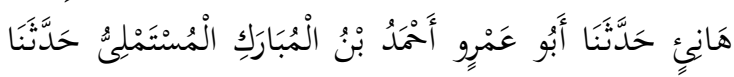

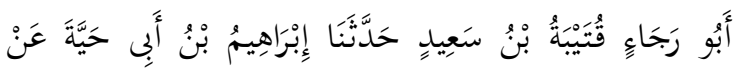

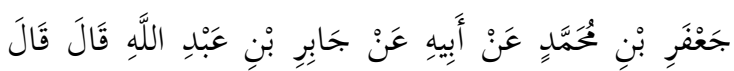

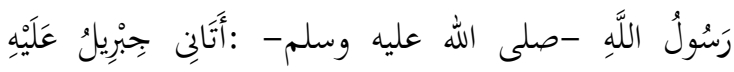

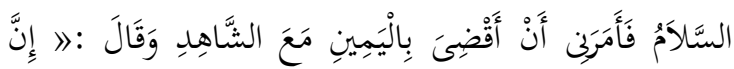

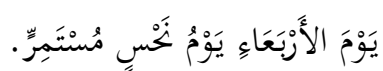
Imam Thabrani juga menyebutkan hadits tersebut dengan redaksi yang sama dalam kitabnya yaitu: 34

عل حدثنا محمد بن عمر بن منصور البجلي الكشي ثنا قتيبة بن إبراهيم بن أبي حية عن جعفر بن محمد عن أبيه

Imam Ibnu Hajar al-'Atsqalani menyebutkan dalam kitabnya bahwa hadits tersebut dikeluarkan oleh Imam Baihaqi dalam "al-Sunan al-Kubra", Imam Thabrani dalam “al-Mu'jam alAusath" dan Ibnu Abd al-Bar dalam

33 Ahmad bin Husain bin Ali bin Musa alKhusraujirdi al-Khurasani Abu Bakar al-Baihaqi, Al-Sunan al-Kubra, Juz 1 (Beirut: Dar kutub al-Ilmiyah, 2003), 286.

34 Sulaiman bin Ahmad bin Ayyub bin Mathir al-Lakhmi al-Syami Abu Qasim al-Thabrani, Al-Mu'jam alAusath, Juz 6 (Kairo: Dar al-Haramain, t.th), 283. 
"al-Tamhid". Semua riwayat dalam kitab-kitab tersebut terdapat satu nama yang dinilai tajrih (cacat) oleh para kritikus hadits yakni Ibrahim bin Abi Hayyah. Bukhari dan Abu Hatim menilainya sebagai munkarul hadits, alNasa'i menilainya dha'if, alDaruquthni menilainya matruk. Jadi hadits tersebut bernilai dha'if karena terdapat satu perawi yang cacat yakni Ibrahim bin Abi Hayyah. ${ }^{35}$

Hadits tersebut menurut pengarang kitab Faidh al-Qadir digolongkan pada hadits dha'if. Dalam kitab tersebut juga disebutkan hadits dengan redaksi yang berbeda yaitu:

$$
\begin{aligned}
& \text { يوم السبت يوم مكر وخديعة ويوم الأحد يوم غرس وبناء } \\
& \text { ويوم الاثنين يوم سفر وطلب رزق ويوم الثلاثاء يوم حديد } \\
& \text { وبأس ويوم الأربعاء لا أخذ ولا عطاء ويوم الخميس يوم } \\
& \text { طلب الحوائج والدخول على السلاطين ويوم الجمعة يوم } \\
& \text { خطبة ونكاح }
\end{aligned}
$$

Hadits tersebut menurut alSakhawi sanad hadits tersebut dha'if sehingga tidak bisa dijadikan sebagai hujjah. ${ }^{36}$
Sanad lengkap hadits tersebut disebutkan dalam kitab Fawaid Tamam yaitu: ${ }^{37}$

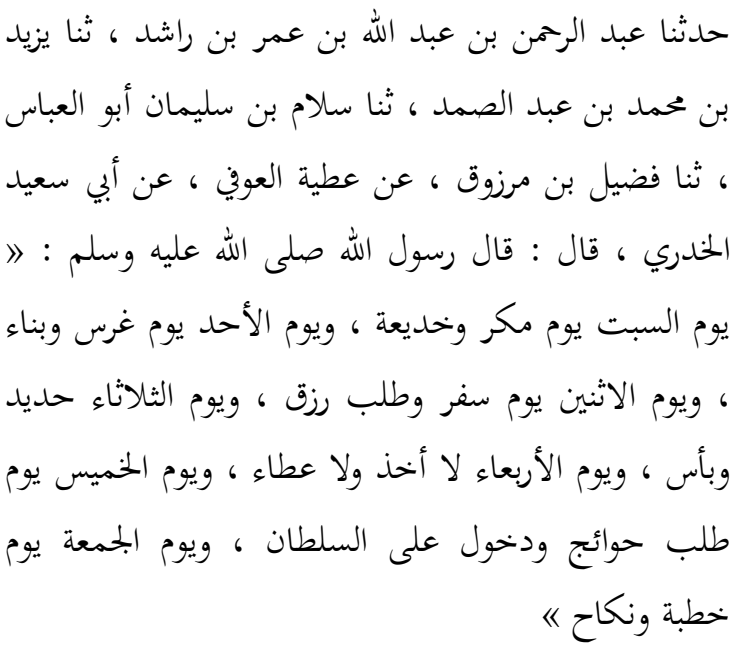

Hadits yang dikeluarkan oleh Abu Qasim Tamam tersebut memiliki kelemahan dalam sanadnya. Salah satu perawi dalam hadits tersebut dinilai lemah oleh ulama' yakni Salam bin Sulaiman Abu Abbas.

Al-Mizi menyebutkan dalam kitabnya beberapa kritikus hadits tentang Salam bin Sulaiman Abu Abbas. Muhammad bin Amr al-'Uqaili menilai "tidak diikuti haditsnya", Abu Ahmad bin 'Adi menilai "munkar alhadits", Abdurrahman bin Abi Hatim menilai "tidak kuat", al-Nasa'i menilai "tsiqah", al-Dzahabi menilai "munkar"

37 Abu al-Qasim Tamam bin Muhammad bin Abdullah bin Ja'far bin Abdullah bin Junaid al-Bajli alRazi, Al-Fawaid, Juz 1 (Riyadh: Maktabah al-Rusrd, 1412 H), 265. 
dan Ibnu Hajar menilai "dha'if ".38

Dengan demikian, karena mayoritas penilai hadits menilainya tajrih, maka dapat disimpulkan bahwa hadits tersebut dha'if karena cacatnya Salam bin Sulaiman Abu Abbas.

$$
\text { Adapun hadits yang }
$$
menyebutkan bahwa hari rabu adalah hari berdarah ditemukan dalam kitab al-Mathalib al-'Aliyah karya Ibnu Hajar al-'Atsqalani dengan redaksi berikut:

قال أبو يعلى : ثنا عمرو بن الحصين ، ثنا يميى بن العلاء ،

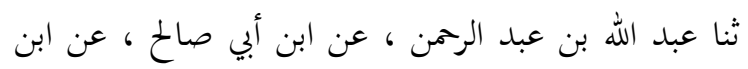

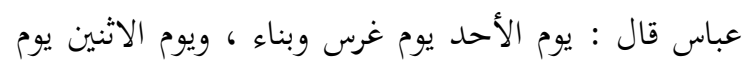

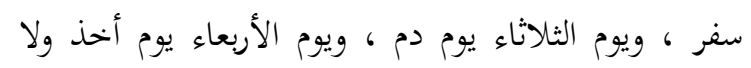
عطاء فيه ، ويوم الخميس يوم الدخول على السلطان ، ويوم الجمعة يوم تزويج وباءة ، ويوم السبت يوم صيد Jika diperhatikan dengan seksama hadits tersebut tidak bersumber dari Nabi Muhammad SAW sehingga tidak layak disebut sebagai hadits Nabi atau hadits marfu' karena hadits tersebut merupakan perkataan Ibnu Abbas.

Selain itu, dalam kitab yang sama juga disebutkan bahwa hadits tersebut sanadnya maudhu' karena ada

38 Yusuf bin Abd al-Rahman bin Yusuf Abu alHajjaj Jamal al-Din ibnu Zaki Abi Muhammad al-Qadha'i al-Kalbi al-Mizi, Tahdzib al-Kamal min Asma' al-Rijal, Juz 12 (Bairut: Muassasah al-Risalah, 1980), 287. salah satu perawi yakni Yahya bin 'Ala' yang dinilai "tertuduh memalsukan hadits". 39

\section{Bersenggama Pada Malam Hari}

Adapun hadits yang menjelaskan waktu yang tepat untuk bersenggama pada malam hari tidak ditemukan dalam kitab-kitab hadits atau tidak jelas sumbernya.

Hadits yang menjelaskan bahwa Rasulullah menikah di bulan Syawal dan melakukan hubungan intim pada bulan Syawal juga banyak ditemukan dalam beberapa kitab hadits seperti Musnad Ahmad, Sunan Tirmidzi, Shahih Muslim, Sunan Nasa'i, Sunan Ibnu Majah dan lain sebagainya ${ }^{40}$ dan termasuk hadits yang shahih berdasarkan penjelasan Imam Tirmidzi. ${ }^{41}$

$$
\text { Adapun hadits yang }
$$
menjelaskan hari tepat bersenggama pada hari minggu (karena hari minggu adalah hari menanam dan

\footnotetext{
${ }^{39}$ Ibnu Hajar al-'Atsqalani, Al-Mathalib al-'Aliyah bi Zawaid al-Masanid al-Tsamaniyah, Juz 14, 149.

${ }^{40}$ Lihat. Ahmad Bin Hanbal, Musnad Ahmad bin Hanbal, Juz 42 (Beirut: Mu'assasah al-Risalah, 2001), 471. Abu Abdullah Muhammad bin Yazid bin Majah alQazwini, Sunan Ibnu Majah, Juz. 3 (Damaskus: Dar Risalah al-Ilmiyah), 157. Abu Isa al-Tirmidzi, Sunan al-Tirmidzi, Juz. 2 (Beirut: Dar Gharb al-Islami, 1998), 392.

41 Abu Isa al-Tirmidzi, Sunan al-Tirmidzi, Juz. 2,
} 
membangun) telah disebutkan pada hadits sebelumnya dan hadits tersebut bernilai maudhu'. Sedangkan hadits lain yang menjelaskan bersenggama yang baik pada hari jum'at (karena termasuk hari meminang dan menikah) juga sudah disebutkan sebelumnya dan haditsnya bernilai dha'if.

Secara umum tidak ada hadits yang khusus berbicara tentang waktuwaktu khusus untuk bersenggama namun jika tiba-tiba nafsu memuncak disebabkan melihat lawan jenis selain pasangan halalnya maka disunnahkan untuk segera melakukan hubungan intim dengan pasangan halalnya. Rasulullah SAW bersabda:

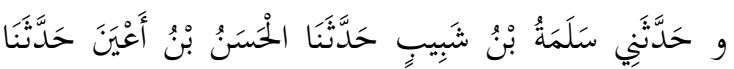

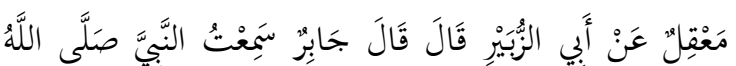

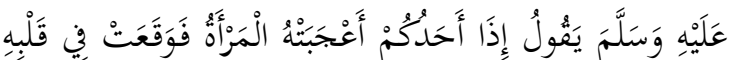

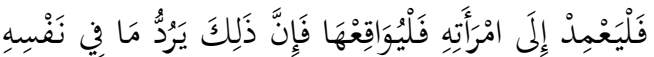
Jika ada lelaki yang terpikat dengan seorang wanita hingga dia jatuh cinta padanya maka hendaknya dia mendatangi istrinya dan melakukan hubungan dengannya.
Dengan ini akan akan menghilangkan perasaan cinta dalam hatinya. ${ }^{42}$

Dengan redaksi yang berbeda imam Tirmidzi menyebutkan: 43

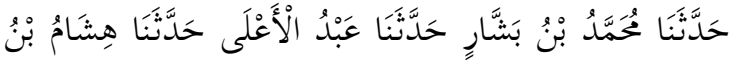

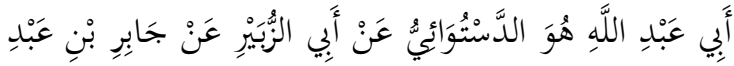

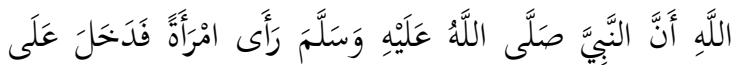

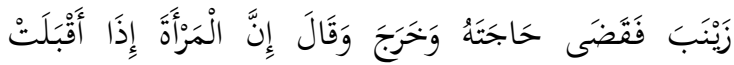

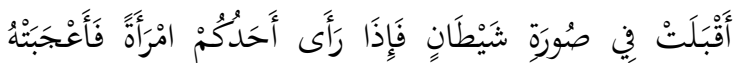

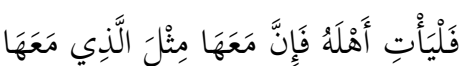

Imam al-Tirmidzi menyebutkan setelah hadits tersebut bahwa hadits tersebut bernilai shahih hasan sehingga bisa dijadikan hujjah.

Terdapat hadits lain yang menjelaskan bahwa mandi pada hari jum'at yang menurut sebagian ulama' juga menjelaskan menggauli pada pada hari jum'at. Imam Tirmidzi menyebutkan dalam kitabnya:44

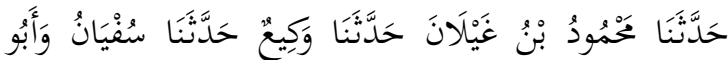

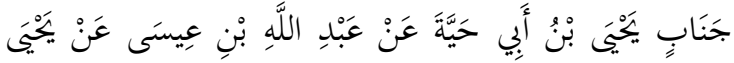

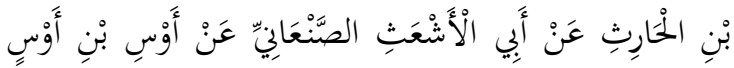

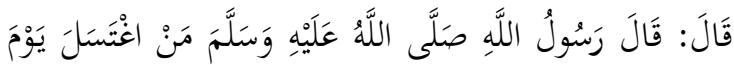

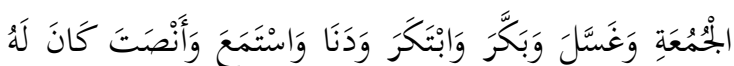

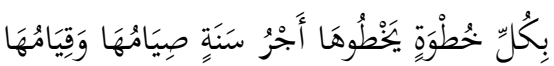

${ }^{42}$ Muslim bin Hajjaj Abu Hasan al-Qusyairi alNaisaburi, Shahih Muslim, Juz 2 (Beirut: Dar Ihya' al-Turats al-'Arabi, t.th), 1021. Ahmad Bin Hanbal, Musnad Ahmad bin Hanbal, Juz 23, 77.

${ }_{43}$ Abu Isa al-Tirmidzi, Sunan al-Tirmidzi, Juz. 2, 455.

${ }^{44} \mathrm{Ibid}, \mathrm{Juz} 1,624-625$. 


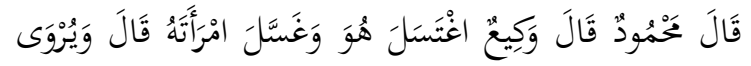

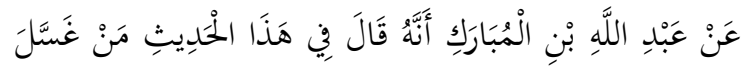

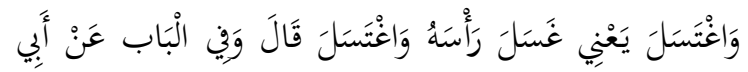

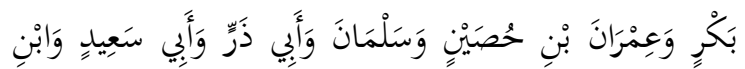

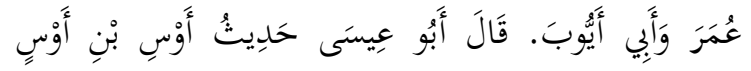

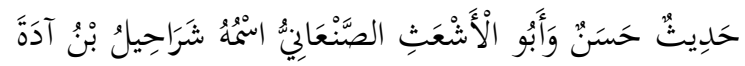

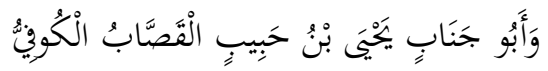
Imam Tirmidzi dalam hadits tersebut menyebutkan bahwa kualitasnya hadits tersebut adalah hasan. Hadits hasan termasuk hadits yang bisa dijadikan sebagai hujjah.

Sebagaimana disebutkan oleh imam Tirmidzi dalam hadits tersebut bahwa ulama' berbeda pendapat tentang kata "غسل". Waqi' memahami kata tersebut sebagai hubungan intim suami istri yang ujungnya pada mandi junub istri. Abdullah bin Mubarak berbeda pendapat dengan Waqi'. Maksud kata "ghassala" menurut Abdullah bin Mubarak adalah membasuh kepala dan meneruskan mandi janabah. Pendapat Abdullah bin Mubarak lebih kuat karena imam Tirmidzi sendiri memberikan judul bab terkait hadits ini dengan judul "mandi pada hari jum'at dan berpagipagi pergi shalat jum'at" .
Jika hadits tersebut dipahami sebagai dalil untuk waktu yang tepat berhubungan intim maka haruslah dipahami secara keseluruhan karena hadits tersebut menjelaskan serangkaian kegiatan seperti hubungan intim (sebagaimana pendapat Waqi'), mandi junub, berangkat pagi untuk shalat jum'at dan diam dan mendengarkan khutbah. Jika hal tersebut dilakukan maka setiap langkah diganjar seperti ibadah satu tahun.

\section{Hadits tentang Adab Bersenggama}

Terdapat banyak hadits yang menjelaskan disunnahkannya berdo'a sebelum melakukan hubungan intim. Hadits-hadits tersebut disebutkan dalam kitab Shahih Bukhari, Shahih Muslim, Sunan Abu Daud, Sunan Tirmidzi, Sunan Nasa'i, Musnad Ahmad bin Hanbal dan lain sebagainya. ${ }^{45}$

${ }^{45}$ Lihat. Muhammad bin Ismail Abu Abdullah al-Bukhari, Shahih Bukhari, Juz 1 (t.tp: Dar Thuq al-Najah, 1422 H), 40. Ahmad Bin Hanbal, Musnad Ahmad bin Hanbal, Juz 17, 88. Abu Abdullah Muhammad bin Yazid bin Majah al-Qazwini Abu Isa al-Tirmidzi, Sunan alTirmidzi, Juz. 2, 392. 
Bukhari menyebutkan dalam kitabnya dengan empat redaksi yang berbeda yaitu:46

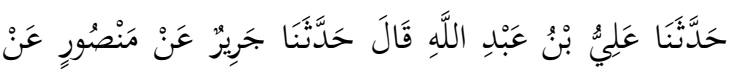

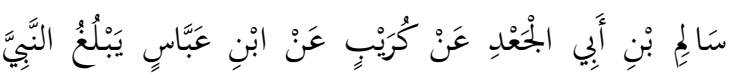

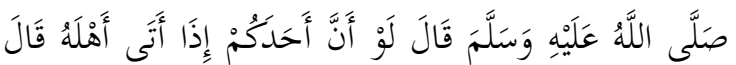

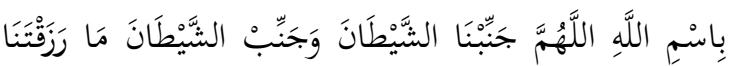

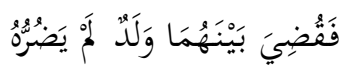

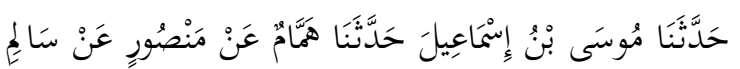

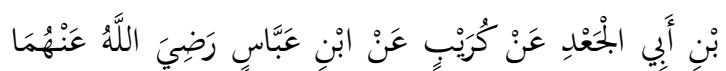

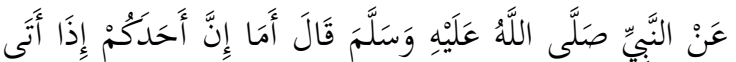

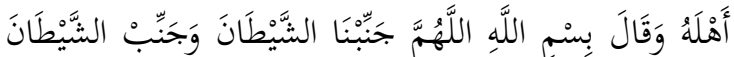

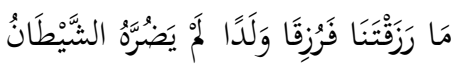

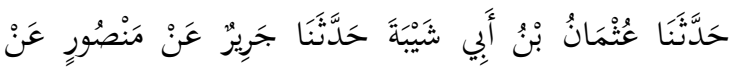

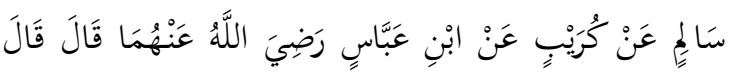

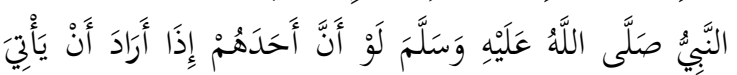

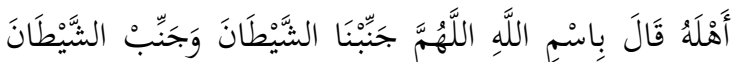

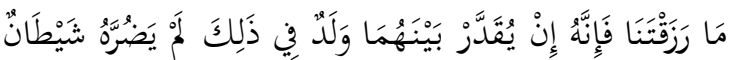

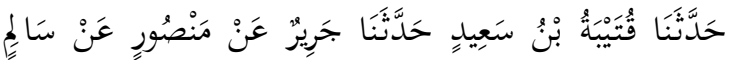

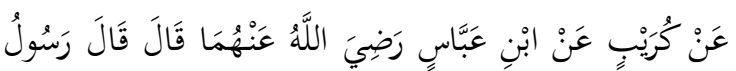

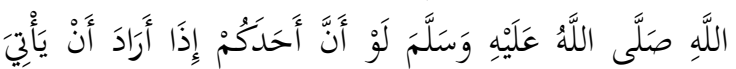

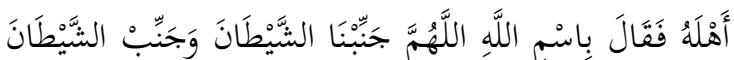

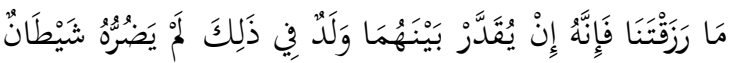

Imam Muslim juga mengeluarkan dengan tersebut yaitu:47

46 Muhammad bin Ismail Abu Abdullah alBukhari, Shahih al-Bukhari, Juz 1, 40, Juz 4, 122, Juz 8, 82 dan Juz 9, 119.

${ }^{47}$ Muslim bin Hajjaj Abu Hasan al-Qusyairi alNaisaburi, Shahih Muslim, Juz 2, 1058.

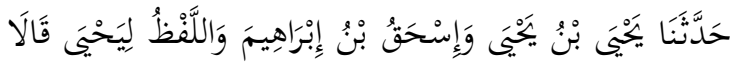

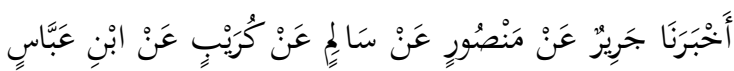

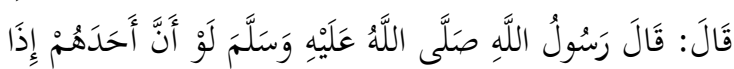

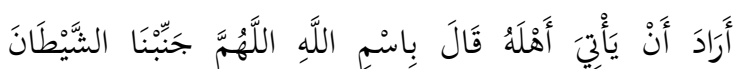

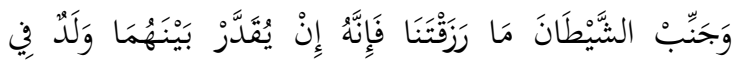

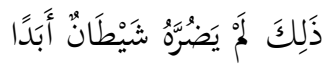

Abu Daud menyebutkan dalam kitabnya:48

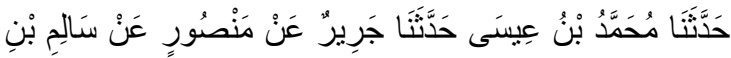

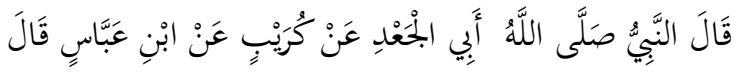

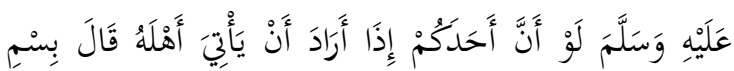

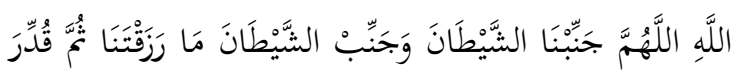

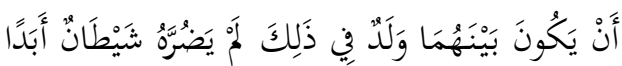

Imam Tirmidzi juga meriwayatkan hadits tersebut dan menyebutkan dalam kitabnya: 49

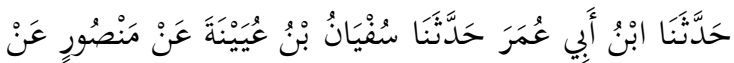

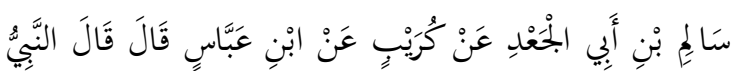

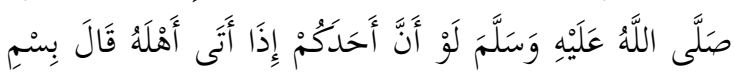

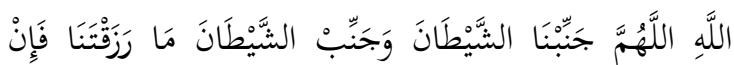

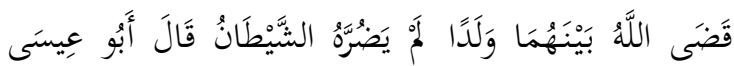

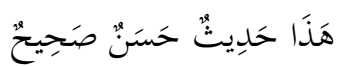
Al-Nasa'i menyebutkan dalam kitabnya:50

${ }^{48}$ Abu Daud Sulaiman bin Asy'ats bin Ishaq bin Basyir bin Syaddad bin Amr al-Azdi al-Sijistani, Sunan Abu Daud, Juz. 3 (Beirut: Maktabah al-Ashriyah, t.th), 489. 393.

${ }^{49}$ Abu Isa al-Tirmidzi, Sunan Al-Tirmidzi, Juz. 3,

${ }^{50} \mathrm{Abu}$ Abd al-Rahman Ahmad bin Syuaib bin Ali al-Khurasani al-Nasa'i, Sunan Nasa'i, Juz. 9 (Aleppo: Maktabah al-Mathbu'ah al-Islamiyah, 1986), 109. 


$$
\begin{aligned}
& \text { أخبرنا إسماعيل بن مسعود قال حدثنا عبد العزيز بن عبد }
\end{aligned}
$$

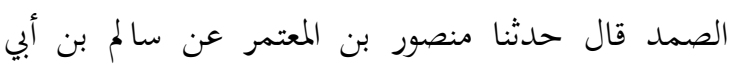

$$
\begin{aligned}
& \text { الجعد عن كريب عن بن عباس أن رسول الله صلى الله عليه } \\
& \text { و سلم قال : لو أن أحدكم إذا أتى أهله قال بسم الله } \\
& \text { اللهم جنبنا الشيطان وجنب الشيطان من رزقتنا فإن قدر } \\
& \text { بينهما في ذلك ولد لم يضر ذلك الولد الشيطان أبدا }
\end{aligned}
$$

Hadits-hadits yang dikeluarkan

oleh Imam Bukhari, Muslim, Abu Daud, Tirmidzi dan Nasa'i memiliki kemiripan dalam lafadz dan sanadnya. Lafadz hadits-hadits tersebut sangat mirip dan hanya sedikit berbeda di bagian akhir. Sanadnya juga hamper sama dan hanya berbeda pada 3 tingkatan perawi terakhirnya.

Imam al-Tirmidzi menilai hadits tersebut hasan shahih ${ }^{51}$ sehingga hadits tersebut bisa dijadikan hujjah.

Adapun doa setelah melakukan hubungan intim tidak ditemukan hadits khusus yang menjelaskan hal tersebut. Namun doa tersebut diambil dari potongan ayat al-Qur'an yakni:

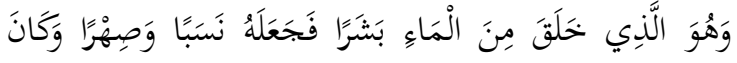

$$
\begin{aligned}
& \text { رَبَّكَ قَدَيرًا }
\end{aligned}
$$

Dan Dia (pula) yang menciptakan manusia dari air lalu dia jadikan manusia itu (punya) keturunan dan mushaharah dan adalah Tuhanmu Maha Kuasa (QS. AFurqan: 54).
Adapun hadits yang menjelaskan untuk tidak telanjang bulat saat bersenggama dinilai $d h a^{\prime}$ if oleh Ibnu Hajar al-'Atsqalani dalam kitab Mathalib al-Aliyah. ${ }^{52}$ Al-Albani menyebutkan bahwa hadits yang dikeluarkan oleh Ibnu Majah tersebut dha'if karena ada salah satu perawi haditsnya yang lemah yakni Ahwash bin Hakim dan Walid bin Qasim alHamdani. ${ }^{53}$

$$
\text { Hadits yang menjelaskan }
$$
keharusan pelan-pelan saat akan akan ejekulasi agar istri juga merasa puas tidak ditemukan dalam kitab hadits atau tidak jelas sumbernya. Meskipun demikian, menggauli istri dengan baik, termasuk saat berhubungan intim, bisa disandarkan pada keumuman ayat alQur'an yakni:

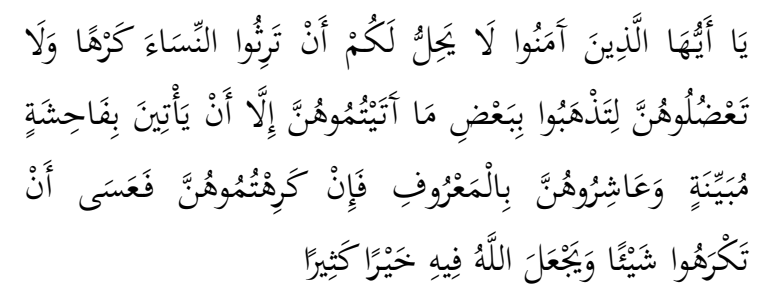

Hai orang-orang yang beriman, tidak halal bagi kamu mempusakai wanita dengan jalan paksa dan janganlah kamu

\footnotetext{
52 Ibnu Hajar al-'Atsqalani, Al-Mathalib al-'Aliyah bi Zawaid al-Masanid al-Tsamaniyah, Juz 8, 231-232.

53 Muhammad Nashiruddin al-Albani, Irgha' alGhalil Fi Takhrij Hadits Manar al-Sabil, Juz 7 (Beirut: Maktab al-Islami, 1985), 71.
} 
menyusahkan mereka karena hendak mengambil kembali sebagian dari apa yang telah kamu berikan kepadanya, terkecuali bila mereka melakukan pekerjaan keji yang nyata. Dan bergaullah dengan mereka secara patut. Kemudian bila kamu tidak menyukai mereka, (maka bersabarlah) karena mungkin kamu tidak menyukai sesuatu, padahal Allah menjadikan padanya kebaikan yang banyak (QS. Al-Nisa': 19).

Sedangkan hadits yang menjelaskan bahwa syahwat ada sepuluh dan 9 dimiliki oleh perempuan namun tertutupi oleh sifat malu dikeluarkan oleh Thabrani dalam $M u^{\prime} j a m$ Ausath dengan redaksi hadits sebagai berikut: 54

وعن المغيرة عن عمرو بن شعيب عن أبيه عن جده عن

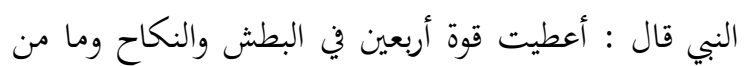

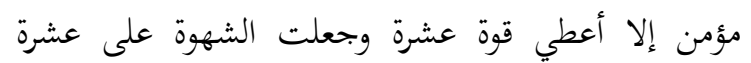

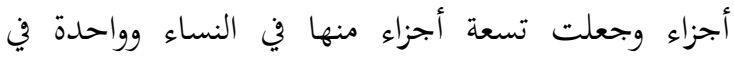
الرجال ولولا ما ألقي عليهن من الحياء مع شهواتن لكان آنساء لكل رجل تسع نسوة مغتلمات

Hadits tersebut dinilai dha'if karena terdapat perawi yang lemah yakni Suwaid bin Abd al-Aziz dan Mughirah bin Qais. Bahkan Suwaid bin Abd al-Aziz termasuk perawi yang

54 Sulaiman bin Ahmad bin Ayyub bin Mathir al-Lakhmi al-Syami Abu Qasim al-Thabrani, Al-Al-Mu'jam al-Ausath, Juz. 1, 178. matruk al-hadits (ditinggalkan

haditsnya). ${ }^{55}$

\section{Hadits tentang Pahala Bersenggama}

Hadits-hadits yang menjelaskan keutamaan bersenggama tidak jelas sumbernya karena tidak terdapat dalam kitab-kitab hadits. Namun ada hadits lain yang menjelaskan pahala memandang dan memegang tangan istri yakni: 56

$$
\begin{aligned}
& \text { إن الرجل إذا نظر إلى امرأته ونظرت إليه نظر الله تعالى }
\end{aligned}
$$

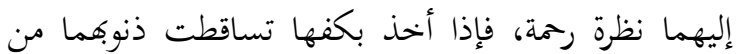$$
\text { خلال أصابعهما }
$$

Selain dalam kitab Faid alQadir, hadits tersebut juga disebutkan dalam kitab Tarikhnya al-Rafi'i yaitu: ${ }^{57}$

$$
\begin{aligned}
& \text { ثنا إسماعيل بن توبة، ثنا الحسين بن معاذ الخراساني، عن }
\end{aligned}
$$

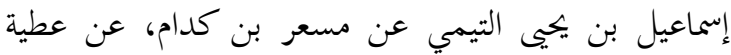

$$
\begin{aligned}
& \text { العوفي عن أبي سعيد المخدري، قال قال رسول الله صلى الله } \\
& \text { عليه وآله وسلم إن الرجل إذا نظر إلى امرأته ونظرت إليه }
\end{aligned}
$$

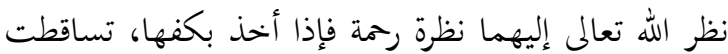

$$
\begin{aligned}
& \text { ذنوبكما من خلال أصابعهما. }
\end{aligned}
$$

Menurut Albani hadits tersebut maudhu' (palsu) karena terdapat perawi hadits yakni Ismail bin Yahya

${ }^{55}$ Muhammad Nashiruddin al-Albani, Silsilah alAhadits al-Dha'ifah wa al-Maudhu'ah wa Atsaruha al-Sayyi' fi al-Ummah, Juz 14 (Riyadh: Maktabah Ma'arif, 1992), 403.

56 Muhammad Abd al-Rauf al-Munawi, Faid alQadir, Juz 1, 415.

57 Abd al-Karim bi Muhammad bin Abd Karim Abu Qasim al-Rafi'I, Al-Tadwin fi Akhbari Qazwin, Juz. 2 (t.t: Dar Kutub al-Ilmiyah, 1987), 47. 
al-Taimi yang merupakan pemalsu hadits. ${ }^{58}$

Namun dalam hadits yang lain disebutkan bahwa berhubungan intim pahalanya seperti bershadaqah. Rasulullah SAW bersabda:

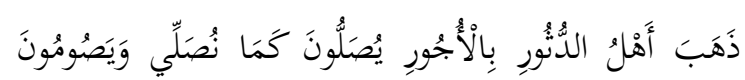

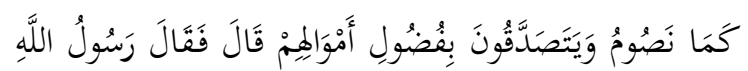

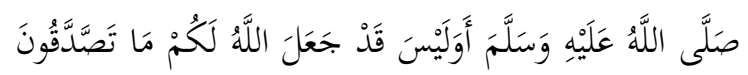

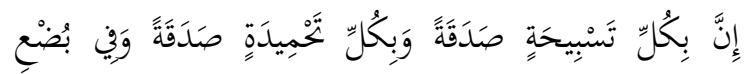

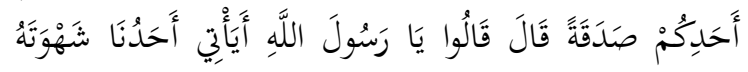

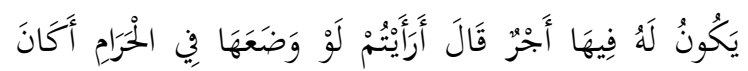

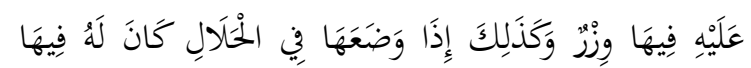

Hadits tersebut dikeluarkan oleh imam Muslim dan imam Ahmad bin Hanbal dan bernilai shahih. ${ }^{59}$

\section{Kesimpulan}

Hadits tentang hari rabu dan sabtu tidak boleh melakukan hubungan intim kualitasnya dha'if sehingga tidak bisa dijadikan hujjah. Sebagaimana dijelaskan dalam kitabkitab ilmu hadits bahwa, menurut ulama' hadits, hadits yang bisa dijadikan sebagai landasan atau hujjah hanyalah hadits-hadits yang

${ }^{58}$ Muhammad Nashiruddin al-Albani. Silsilah alAhadits al-Dha'ifah wa al-Maudhu'ah wa Atsaruha al-Sayyi' fi al-Ummah, Juz 7, 274-276. Juz 35,376 . kualitasnya shahih atau hasan. Adapun hadits-hadits yang bernilai dha'if, menurut jumhur ulama hadits, tidak bisa dijadikan sebagai landasan hukum kecuali dalam keutamaan amal saja dan dengan syarat-syarat yang sangat ketat. Salah satu syarat diperbolehkannya hadits dha'if digunakan dalam keutamaan amal adalah alasan kelemahan hadits tersebut tidaklah parah dan juga tidak boleh beranggapan bahwa hal itu merupakan hadits yang bersumber dari Rasulullah SAW.

Hadits yang menjelaskan dianjurkannya bersenggama pada malam hari tidak ditemukan dalam kitab-kitab hadits dan tidak jelas sumbernya. Sedangkan hadits tentang waktu yang tepat untuk menikah dan berhubungan intim pada bulan syawal bernilai shahih dan banyak disebutkan dalam kitab-kitab hadits utama. Adapun hadits tentang waktu yang dianjurkan berhubungan intim pada hari minggu haditsnya bernilai dha' if.

Hadits tentang anjuran berdoa sebelum bersenggama bernilai shahih dan disebutkan dalam kitab hadits yang utama. Sedangkan doa 
setelahnya memang tidak ditemukan dalam kitab hadits namun didasarkan pada ayat al-Qur'an surah al-Furqan: 54.

$$
\text { Adapun hadits yang }
$$
menjelaskan tentang anjuran tidak telanjang bulat saat berhubungan intim dan dan hadits tentang pelanpelan saat berhubungan intim agar istri merasa puas bernilai dha'if. Namu al-Qur'an surah al-Nisa': 19 secara umum menyerukan untuk menggauli istri dengan baik termasuk pada saat berhubungan intim.

Hadits-hadits yang menjelaskan pahala berhubungan intim yang berlipat-lipat tidak jelas sumbernya dan tidak ditemukan dalam kitab hadits. Meski demikian, dalam hadits yang shahih disebutkan bahwa pahala berhubungan intim seperti pahala bershadaqah. Disebutkan dalam hadits shahih tersebut bahwa dengan melakukan hubungan intim dengan istrinya maka sebenarnya sudah menghindarkan diri dari perbuatan tercela seperti berzina dan semacamnya. Oleh karena itulah pahala berhubungan intim adalah seperti pahala bersedekah di jalan Allah SWT.

\section{Referensi}

1. al-'Atsqalani, Ibnu Hajar, Al-Mathalib al-'Aliyah bi Zawaid al-Masanid alTsamaniyah, Riyadh: Dar al-'Ashimah al-Mamlakah al-'Arabiyah alSaudiyah, 1998.

2. al-Albani, Muhammad Nashiruddin, Irgha' al-Ghalil Fi Takhrij Hadits Manar al-Sabil, Beirut: Maktab al-Islami, 1985.

3. al-Albani, Muhammad Nashiruddin, Silsilah al-Ahadits al-Dha'ifah wa alMaudhu'ah wa Atsaruha al-Sayyi' fi alUmmah, Riyadh: Maktabah Ma'arif, 1992.

4. al-Atsir, Ibn, al-Nihayah fi Gharib alHadis wa al-Atsar, Mesir: Isa al- Babi, 1963.

5. al-Baghdadi, Khathib, Kitab al-Kifayah Fi Ilm Al-Riwayah, Mesir: Mathba'ah alSa'adah, 1972.

6. al-Baihaqi, Ahmad bin Husain bin Ali bin Musa al-Khusraujirdi al-Khurasani Abu Bakar, Al-Sunan al-Kubra, Beirut: Dar kutub al-Ilmiyah, 2003.

7. al-Bukhari, Muhammad bin Ismail Abu Abdullah, Shahih Bukhari, t.tp: Dar Thuq al-Najah, $1422 \mathrm{H}$

8. al-Damini, Maqayis Naqd Mutun alSunnah, Riyadh: t.p, 1984.

9. Dhofier, Zamakhsyari, Studi Pesantren; Studi tentang Pandangan Kyai, Jakarta: LP3ES, 1982.

10. Haedari, HM. Amin, et.al, Masa Depan Pesantren dalam Tantangan Modernitas dan Tantangan Kompleksitas Global, Jakarta: IRD Press, 2005.

11. Hanbal, Ahmad Bin, Musnad Ahmad bin Hanbal, Beirut: Mu'assasah alRisalah, 2001.

12. Ismail, M. Syuhudi, Metodologi Penelitian Hadis Nabi, Jakarta: Bulan Bintang, 2007. 
13. Khon, Abdul Majid, Ulumul Hadits, Jakarta: Amzah Press, 2010.

14. Mandzur, Ibnu, Lisan al-Arab, Beirut: Dar Lisan al-Arab, tt.

15. al-Mizi, Yusuf bin Abd al-Rahman bin Yusuf Abu al-Hajjaj Jamal al-Din ibnu Zaki Abi Muhammad al-Qadha'i alKalbi, Tahdzib al-Kamal min Asma' alRijal, Bairut: Muassasah al-Risalah, 1980.

16. al-Munawi, Muhammad Abd al-Rauf, Faid al-Qadir, Beirut: Dar al-Fikr, 1996.

17. al-Naisaburi, Muslim bin Hajjaj Abu Hasan al-Qusyairi, Shahih Muslim, Beirut: Dar Ihya' al-Turats al-'Arabi, t.th.

18. al-Nasa'i, Abu Abd al-Rahman Ahmad bin Syuaib bin Ali al-Khurasani, Sunan Nasa'i, Aleppo: Maktabah alMathbu'ah al-Islamiyah, 1986.

19. Qadir, Abd. Muhdi Abdul, Turuqu Takhrij Hadith Rasulillah, Kairo: Dar I'tisahm, 1986.

20. al-Qazwini, Abu Abdullah Muhammad bin Yazid bin Majah, Sunan Ibnu Majah, Damaskus: Dar Risalah al-Ilmiyah.

21. al-Rafi'i, Abd al-Karim bi Muhammad bin Abd Karim Abu Qasim, Al-Tadwin fi Akhbari Qazwin, t.t: Dar Kutub alIlmiyah, 1987.

22. al-Shieddieqy, Teungku Muhammad Hasbi, Sejarah dan Pengantar Ilmu Hadis, Semarang: Pustaka Rizki Putra, 2009.

23. al-Sijistani, Abu Daud Sulaiman bin Asy'ats bin Ishaq bin Basyir bin Syaddad bin Amr al-Azdi, Sunan Abu Daud, Beirut: Maktabah al-Ashriyah, t.th.

24. al-Tahami, Muhammad bin Madani, Qurratul Uyun; Fi al-Nikah al-Syar'i, t.tp: t.p, t.t.

25. al-Thabrani, Sulaiman bin Ahmad bin Ayyub bin Mathir al-Lakhmi al-Syami Abu Qasim, Al-Mu'jam al-Ausath, Kairo: Dar al-Haramain, t.th.
26. Thahhan, Mahmud, Taisir Mustalah alHadits, Bairut: Dar Al-Qur'an Karim, 1979.

27. al-Tirmidzi, Abu Isa, Sunan al-Tirmidzi, Beirut: Dar Gharb al-Islami, 1998. 